\title{
"The Pilgrim Predestined and His Brother Reprobate": Jesuit Formative Paths in the Seventeenth Century
}

\author{
Marina Massimi \\ Universidade de São Paulo \\ mmarina@ffclrp.usp.br
}

\begin{abstract}
The article analyzes the allegorical Brazilian novel História do Predestinado peregrino e de seu irmão Precito (The story of the pilgrim Predestined and his brother Reprobate) (1682) in the light of the history of psychological knowledge. The novel's author, Alexandre de Gusmão (1695-1753), was an important member of the Society of Jesus in Brazil who became the director of Jesuit schools in the region. The article shows that the novel proposes a link between the psychological and spiritual dimensions, a link necessary for health and decisive in the healing of mental disorders. The role of psychological dynamism depends on the choice of an appropriate target or, in other words, on appetites being directed toward an appropriate object.
\end{abstract}

\section{Keywords}

Jesuit psychological knowledge - literature and psychology - pilgrimage - Alexandre de Gusmão - História do Predestinado peregrino e de seu irmão Precito - allegorical novel

\section{Introduction}

In this essay, a cultural history perspective is used to analyze a text popular from the late seventeenth and through the eighteenth century: the allegorical novel História do Predestinado peregrino e de seu irmão Precito (The story of the 
pilgrim Predestined and his brother Reprobate), published in $1682 .{ }^{1}$ The author, Alexandre de Gusmão (1695-1753), was a member of the Society of Jesus in Brazil. He served as director of the seminary of Belém, a boarding school in Cachoeira do Campo, near the city of Salvador.

The book used the rhetorical devices of the allegorical novel to convey the educational approach proposed by Ignatius of Loyola $(c .1491-1556)$ and the Society of Jesus. This approach involved the mobilization of the psychological dynamism of its recipients, as understood by the philosophical and rhetorical traditions of the Western world that gave rise to the Society.

The methodological approach for this study was suggested by the multidimensional historiographical model proposed by Michel de Certeau (1925-86), which is useful for addressing multifaceted and complex aspects of history, in which both oral and written expression must be considered. De Certeau suggests that, especially in the modern age, the universe of practices (social, religious, and cultural) must be addressed in an articulate manner that complements the conceptual universe as a whole. Indeed, in many cases, the universe of practice proves to be the best means of transmitting a specific universe of ideas. $^{2}$

The socio-cultural world of Brazil's colonial period, extending from the sixteenth to the early nineteenth century, was predominantly marked by orality. The dimensions of this practice and the ideas involved proceed in unique ways, each following its own logic and rate of growth. Ideas are dimensioned by the worldview of the cultural productions of the time, whereas the dimension of the practices is that set of gestures, actions, habits, and rituals that intertwine the daily lives of the people. This dimension expresses and provides ownership and transmission of the everyday meanings inherent to that particular worldview. Thus, resuming the objectives and purpose of our study, the novel was designed to convey certain ideas and values to the reader, but it also suggested practices which would (supposedly) lead to the learning of a method of attaining self-knowledge and the evaluation of actions in relation to the values that inspired them.

1 Alexandre de Gusmão, História do Predestinado peregrino e de seu irmão Precito (Lisbon: Deslandes,1682). Here I quote from the 1685 edition.

2 Michel de Certeau, The Writing of History, trans. Tom Conley (New York: Columbia University Press, 1988). 
In Europe, the Society aimed at creating bridges between the heritage of medieval Catholicism and the new spirit of the Renaissance. ${ }^{3}$ Present in Brazil since 1549, Jesuit missionaries engaged in "translating" Western anthropological and psychological conceptions into a way of educating native peoples. This training was designed to contribute both to the evolution from childhood to maturity through education and to the process of the acculturation of the Amerindians, Africans, and Far-Eastern peoples to Christianization. For at least two centuries, the Jesuits constituted an important cultural and social presence in Brazil: they were responsible for creating the first school system in the country and for elaborating numerous cultural projects integrating indigenous and European cultures in relation to the knowledge of man in its various dimensions. However, the Jesuits were restricted not only by the speculative nature of their philosophical anthropology, but also by their approach to the development and dissemination of an "art of living" that focused on the demands of individual and social life and on practices such as spiritual direction and the examination of conscience, developed in and systematically used by the Society's schools. In this context, psychological dynamism assumed special importance in the intersection of the substrate of the body and the spiritual life, an aspect to which the Jesuits gave special attention.

From the perspective of the Jesuit philosophers who influenced the early modern Luso-Brazilian context, all knowledge had to be based on experience. By "experience" they understood a form of knowledge gained on the basis of action (modus operandi) and previous (and/or consecutive) thoughts (modus cogitandi). This is a knowledge that involves all psychological powers, the five senses, affection, understanding, and desire and leads to truth and goodness. ${ }^{4}$

Preaching and education were privileged fields of ministry for the Society in Brazil. The sermons preached by Jesuits in colonial Brazil were the product of articulated and intentional construction, designed to promote knowledge, persuade, and modify behavior through the mobilization of the psychological

3 See Luce Giard and Louis de Vaucelles, eds., Les jésuites à l'âge baroque, 1540-1640 (Grenoble: Millon, 1996); Luce Giard, ed., Les jésuites à la Renaissance: Système éducatif et production du savoir (Paris: PUF, 1995).

4 See the expression of Manoel de Góis in his commentary on Aristotle's Ethics: "That which can be experienced by someone and attain a designed goal in relation to that person may be good and convenient." Manoel de Góis, Disputas do curso sobre os livros da moral da Ética a Nicomaco, de Aristóteles em que se contêm alguns dos principais capítulos da Moral, trans. Antônio Banha de Andrade (Lisbon: Instituto de Alta Cultura, 1957), 69. 
dynamism of the recipients. On the other hand, their pedagogical commitment led the Jesuits to the use of various cultural resources available at the time: theater, music, poetry, and narratives. One of these was the particular novel investigated here.

\section{The Author and the Novel}

Alexandre de Gusmão was born in Lisbon in 1629 and died in Bahia in 1724 . He came to Brazil at the age of ten, joined the Society of Jesus at the college of Bahia in 1646, and later held various positions in different schools: prefect, master of novices, and teacher of the humanities in Rio de Janeiro, director of the schools in Santos and Bahia. In 1686, he founded the Seminary of Belém in the city of Cachoeira do Campo, near Salvador. It was an institution that welcomed students from all over Brazil, mainly from the rural areas of Bahia, including the poor and the children of farmers. There, for seventy-three years, some 1,500 Brazilian students received their first formal education.

Gusmão was the author of numerous texts with a wide circulation in Brazil at the time. ${ }^{5}$ In The Story of the Pilgrim Predestined, two brothers were taken on a pilgrimage in search of a city where they could settle down. ${ }^{6}$ This is a metaphor of human existence that can be analyzed from various different perspectives: literary, rhetorical, pedagogical, theological, and political. This text highlighted mobilization driven by impulses provided by the psychological dynamism of the readers, similar to that produced by the practice of the Spiritual Exercises. The novel made use of the cultural resources widely available at the time: philosophical knowledge about the nature of human beings, the tradition of medicine for the soul, and rhetoric. The philosophical principles of the Jesuits in Brazil at that time were inspired by the Platonic-Augustinian and Aristotelian-Thomist traditions, as reinterpreted by the Jesuit scholars and teachers at the College of Arts in Coimbra, authors of the Conimbricenses textbooks. The concepts of medicine for the soul were inspired by the medical tradition inaugurated by Plato's (d. c.348 вСЕ) Timaeus, the humoral theories of Hippocrates (d.370 BCE) and Galen (d.c.20o), and the tradition of the Spiritual

5 Alexandre de Gusmão, Arte de criar bem os filhos na idade da puerícia (Lisbon: Deslandes, 1685); Gusmão, A escola de Belém:Jesus nascido no presépio (Evora: Officina da Universidade, 1678); Gusmão, Menino christão (Lisbon: Deslandes, 1695); Gusmão, Maria Rosa de Nazaret nas montanhas de Hebron, a Virgem nossa Senhora na Companhia de Jesus (Lisbon: Deslandes, 1715); Gusmão, Eleição entre o bem e o mal eterno (Lisbon: Oficina da Música, 1720).

6 Gusmão, História. 
Exercises. ${ }^{7}$ Knowledge of rhetoric oriented the communicative practices used to transmit the doctrinal content and to persuade the recipients to changes in behavior.

Gusmão's novel was intended both to be listened to by those unable to read and write, and to be read by the more educated. Attention to the recipient was important in the construction of the work: in the introduction, Gusmão stated that he wanted to provide the reader with "a roadmap to everlasting life or death, so that it governs his steps." ${ }^{\text {T }}$ Thus, Gusmão revealed that the novel had the same purpose of the Spiritual Exercises: instructing the readers, orienting their lives to choose the greater good, and guiding them on an orderly path without getting distracted by disordered affections.

It is thus necessary to know oneself. Gusmão declared that through the novel he intended to provide a mirror for the readers so they could "see" their own condition and, if necessary, change the course of their lives. The choice of a parable for narrating the story, and the consequent use of the rhetorical devices of metaphor and example, was designed to "provoke the reader's curiosity" and to imitate the original mode of transmission for Christian doctrine since its origins. ${ }^{9}$

4

\section{The Genre of the Novel}

The novel centers on a pilgrimage by two brothers: Predestined and Reprobate. It is organized into six parts, corresponding to six imaginary places (cities), which embody a kind of ideal topology (determined by imagination and memory, as in the long tradition of the art of memory and the Ignatian method of meditation). The two protagonists embark on a long journey aimed at reaching the city where they intend to establish their final abode. Their paths will take them to Jerusalem or Babylon. The path consists of different geographical environments: hills, valleys, towns, and so on. These places acquire metaphorical meaning, and contain various characters allegorizing moral and spiritual dispositions. The pilgrims' journey acquires a clear symbolic meaning, representing the journey of all human existence, which is marked by a linear temporality and defined by an origin and a destination. In this sense, according to Gusmão, "the story of everyone who follows the steps that this life brings,

7 See, Pierre Hadot, Esercizi spirituali e filosofia antica, trans. Anna Maria Marietti (Turin: Einaudi, 2005).

8 Gusmão, História, Prologue.

9 Ibid. 
following the path he/she has chosen, is either saved or condemned."10 The universality of the novel's message is emphasized by the nature of the practice of a pilgrimage. A journey in search of the center, or back to a lost or forgotten homeland, is one of the great mythic archetypes of humanity, present in the literature and religions of all times and peoples of the world. This travel may indicate either movement from one place to another, or passage from the everyday world to another dimension of life, the sacred. In any case, the homeland, feelings, and habits of ordinary life must be voluntarily abandoned by the participant if he/she is to move to the destination, along a route that can be long and dangerous. The word "pilgrimage" is of Latin origin, from the verb peragere (wander through to the end, to completion). Therefore, the pilgrim is not just a foreigner, a traveler, a stateless person. His/her true homeland is the goal, the destination of the journey; his/her life is defined by the pilgrimage from the land of exile to the homeland. ${ }^{11}$ Pilgrimage, common among the Portuguese, was and is widespread in Brazil. In the indigenous tradition too, pilgrimages in search of a "land without evil" were customary..$^{12}$ For example, in the north of the country, the chronicle of the Jesuit João Felipe Bettendorff (1625-98) recorded the existence of pilgrimages to the village of Vigia from 1698 onwards, a village where a miraculous image of the Virgin of Nazareth was to be found. This practice gave rise to the worship of the Virgin of Nazareth and still takes place in Belém and other towns of Pará; it was also spread by emigrants from Pará to various other parts of Brazil. ${ }^{13}$

According to Mary Carruthers, the pedagogical dimensions of the practice of pilgrimages are characterized by the process known as ortopraxi (the building of a disciplined experience that allows a user to identify an experience as original and constitutive)..$^{14}$ Crucial to this process are the use of images and the mobilization of memory, which do not transmit meanings as such, but rather provide support for thought. The arrangement of images does not obey the rules of content, but should serve to create networks of useful concepts

10 Ibid.

11 See Robert Oursel, Pèlerins dul Moyen Age (Paris: Fayard, 1978); Franco Cardini, Gerusalemme d'oro, di rame, di luce: Pellegrini, crociati, sognatori d'Oriente fra XI eXV secolo (Milan: Il Saggiatore, 1991).

12 Mircea Eliade, "Paradiso e utopia: Il messianismo nella società americana," I quaderni di Avallon: Rivista di studi sull'uomo e sul sacro 24 (1991): 29-50.

13 See João Felipe Bettendorff, Crônica dos padres da Companhia de Jesus no Estado do Maranhão (Belém: Fundação Cultural do Pará Tancredo Neves-Secretaria de Estado da Cultura, 1990).

14 Mary Carruthers, The Craft of Thought: Meditation, Rhetoric, and the Making of Images, 400-1200 (Cambridge: Cambridge University Press, 1998). 
and fix them in memory. Aesthetic form and the sensory and emotional appeals evoked by them are therefore functional in the exercise of reflection. Thus, in the medieval pilgrimages, for instance, "physical activity involved in moving from one place to another faithfully mirrored the mental activity in which the participants of the procession engaged."15

In the imaginary pilgrimage of Gusmão's novel, the places and images encountered by the travelers acquir allegorical meanings. Zulmira dos Santos stressed the importance of tradition in the Ibero-Lusitanian context, noting that during the first decades of the seventeenth century, the Arcadian literary movement in Portugal repeatedly featured pilgrimages and the use of allegories. ${ }^{16}$ Dos Santos also suggest that Ignatius of Loyola referred to this tradition in his Spiritual Exercises. Indeed, the image of a pilgrimage to Jerusalem was very special for Ignatius. In his so-called autobiography, narrated in the third person, Loyola would have recounted the beginnings of his conversion, recalling that "when he thought of going to Jerusalem barefoot [...], not only was he consoled when he had these thoughts, but even after putting them aside he remained satisfied and joyful." 17

Besides the use of the pilgrimage metaphor as the core of the narrative, the allegorical character of the novel is shaped by the rhetorics of the modern age. This character is sustained by the use of allegorical figures as characters and by detailed explanations of small frames, formulated as allegories and empresas (emblems). Allegories and empresas are genres that center upon either an image or a written text. Such images depict objects illustrating a particular concept, accompanied by an explanation. The culmination of the use of such allegorical images is the work of Andrea Alciato (1492-1550), which provides an absolute prototype for the genre. In the novel, Gusmão makes explicit reference to Alciato's text. ${ }^{18}$ In cultural and religious practices, images of various kinds (paintings, statues, badges, empresas, metaphors, and allegories) serve as rhetorical devices to evoke a certain response. The effectiveness of this development, then, depends on the activation of psychological processes, especially sensory and imaginative activity (inner senses), to reach the final goal.

15 Ibid., 68.

16 Zulmira dos Santos, Emblemática, memória e esquecimento: A geografia da salvação e da condenação nos caminhos do "prodesse ac delectare" na História do Predestinado Peregrino (1682) de Alexandre de Gusmão sJ [1629-1724] (Porto: Universidade do Porto Faculdade de Letras, 2004).

17 Ignatius of Loyola, Autobiography, n. 8.

18 Andrea Alciato, Emblematum liber (Augsburg, Heinrich Steyner: 1531); see Gusmão, Historia, 135 . 
The use of allegory and knowledge of empresas is not only original to Gusmão, but "it reveals the appreciation that the Society gave to the emblematic figure and the importance the Jesuits granted to the libri figurati." ${ }^{19}$ The use that the Society made of allegories and empresas resulted from two spiritual and pedagogical characteristics of the Ignatian charism. First, an image could convey a sacred message, as Ignatius stressed in the Exercises. Secondly, Loyola considered the image to be particularly effective given its impact on the psychological dynamism of the viewer, especially the memory and the imagination, and in facilitating meditation. In this vein he defined the method of compositio loci (composition of place), which assumed a distinction between narrative and symbolic images. Indeed, in the first prelude of the first exercise, Ignatius refers to two different ways of presenting a visual construction, distinguishing between the res corporea (visible theme), that is, images as narrative, and the res incorporea (invisible theme), concepts and arguments that can only be represented symbolically. At first, Loyola recommends the visible composition of the environment, with the composition of the image consisting of visualizing the material place where an object was to be contemplated, using one's imagination. This could be a material place (a church or a mountain), as in the scenes described in the gospels. In the contemplation of or meditation upon an abstract theme, such as sin, the composition was to be perceived from its effects from the point of view of imagination, considering the souls and bodies of man as distinct from those of the animal world. Ignatius realized, however, that it would not be enough just to use a mental picture for meditation, and also suggested the use of concrete images (whether pictures, prints, or statues)..$^{20}$

The use of images thus plays a pedagogical role. In Jesuit colleges, the composition of allegories was a didactic exercise provided for in the 1599 edition of

19 Dos Santos, Emblemática, 592. A significant document regarding the use of images in spiritual literature produced by the Jesuits is the book Imago primi saeculi (1640) produced by the Society's college in Antwerp. See Lydia Salviucci Insolera, LImago primi saeculi (1640) e il significato dell'immagine allegorica nella Compagnia di Gesù: Genesi e fortuna del libro (Rome: Editrice Pontificia Università Gregoriana, 2004); John W. O'Malley, ed., Art, Controversy, and the Jesuits: The Imago primi saeculi (1640) (Philadelphia: Saint Joseph's University Press, 2015).

20 In the late eighteenth century, the Jesuit Jerónimo Nadal undertook the project of developing an intuitive optic method for prayer with the publication of Adnotationes et meditationes in Evangelia quae in sacrosancto Missae sacrificio toto anno leguntur cum eorundem Evangeliorum concordantia (Antwerp: Moretus, 1593). Jerónimo Nadal, Imagines de la historia evangélica, ed. Alfonso Rodríguez G. de Ceballos (Barcelona: El Albir, 1975). 
the Ratio studiorum. ${ }^{21}$ Gusmão's novel seems to have been written in keeping with this orientation.

Memory in Gusmão's Story is more than a pedagogical tool along the path to spiritual perfection, but rather "a fundamental feature of the itinerary leading to Jerusalem." ${ }^{22}$ Indeed, to achieve the desired goal, Christians must remember that throughout their lives, only "the eternal [is] that which is true, and all that is limited by time is deceptive."23

The pedagogical importance of Gusmão's novel in Brazil arose from its aim of disseminating knowledge and principles to a largely illiterate population composed of Indians, Portuguese colonists, and African slaves. This was the population the Society's missionary work was intended to reach. In fact, education was considered by the Jesuits to be the principal way of christianizing these peoples. ${ }^{24}$ Moreover, as we have seen, the composition of the novel relied on various rhetorical devices designed to facilitate communication: among them, the use of the emblematic figure, popular at the time, which made it possible for a book to contain no images, thus lowering the cost and facilitating wide diffusion. As for the cost of the book, Abreu stated that it was not too high and that in an inventory, Gusmão's book was considered worthless. ${ }^{25}$

How widespread was reading in colonial Brazil? If the habit of reading were generally limited and family libraries were modest and meager, the libraries of the Jesuit colleges were rich: in a 1694 inventory of the library of the school at Bahia totaled approximately three thousand copies, while another in 1718 of that of Para recorded 1,263 volumes; that of Rio de Janeiro contained about five

21 In the thirteenth chapter, devoted to guidelines for teachers of rhetoric and humanities, the Ratio suggests that students be taught to draw pictures to illustrate the allegories, and that teachers write books devoted to the subject. Among them: Antonio Possevino, Bibliotheca selecta (Rome: Typografia Apostolica Vaticana, 1593, ch. De poesi et pictura); Louis Richeome, Trois discours pour la religion catholique: Des miracles, saint et des images (Bordeaux: Millange, 1597). See Giard and Vaucelles, Les jésuites à l'âge baroque; Giard, Les jésuites á la Renaissance.

22 Dos Santos, Emblemática, 595.

23 Ibid., 595-96.

24 See Amarilo Ferreira Junior and Marisa Bittar, "Educação jesuítica e crianças negras no Brasil colonial," Revista brasileira de estudos pedagógicos 80, no. 196 (1999): 153-94; Ferreira Junior and Bittar, "Pluralidade linguística, escola de bê-á-bá e teatro jesuítico no Brasil do século XVI," Educação e sociedade 25, no. 86 (2004): 171-95; Alexandre Shigunov Neto and Lizete Shizue Bomura Maciel, "O ensino jesuítico no período colonial brasileiro: Algumas discussões," Educar em revista 31 (2008): 169-89.

25 See Márcia de Abreu, "Quem lia no Brasil colonial?," Intercom: Sociedade Brasileira de Estudos Interdisciplinares da Comunicação (2011): 1-18. 
thousand books. ${ }^{26}$ These data highlight the importance the Society accorded books and the practice of reading.

We know that there were two editions of the book shortly after it was written: one in 1682 and the other in 1685 . Moreover, a later allegorical novel written by a student of the Jesuit school in Brazil, the Compêndio narrativo do peregrino de América of Nuno Marques Pereira $\left(165^{2-1728)},{ }^{27}\right.$ was published six times between 1725 and 1765 . This text includes various explicit references to the story of the Pilgrim Predestined and to Gusmão.

\section{5}

\section{Values and Concepts Transmitted by the Novel}

The pilgrimage is a metaphor for human life; it is understood as a temporal path framed by an origin and a direction to be followed in an attempt to reach a final destination. In this sense, values are inherent in the orientation of men to time, indicating the behaviors to be adopted if the destination is to be successfully reached. In Gusmão's text, two fundamental values are in evidence: freedom as a decisive action necessary for people to reach their destinations and the importance of education in the formation of a person.

In the novel, the author's intention was to point out the crucial role of free will in the design of personal history, purposefully stressed to counteract Protestant theological accounts of the concept (exemplified by John Bunyan's [1628-80?] 1678 work, The Pilgrim's Progress from This World to That Which Is to Come:Delivered under the Similitude of a Dream). ${ }^{28}$ The spread of Protestant ideas in colonial Brazil is associated with two streams, one in the sixteenth century and the other in the seventeenth, in various regions of the country. The first influx occurred between 1555 and 1567 in the bay of Guanabara (now Rio de Janeiro), mediated by French Calvinists, who brought pastors to these lands as missionaries. Among them was Jean de Lery, author of "History of a Journey

26 Mark Glover, "The Book and the Conquest: Jesuit libraries in Colonial Brazil," Libraries and Culture 28, no. 3 (1993): 271-73; Luiz Carlos Villalta, "Os leitores e os usos dos livros na America Portuguesa," in Leitura, história e história da leitura, ed. Márcia Abreu (Campinas: Mercado de Letras-Associação de Leitura do Brasil \& São Paulo-Fapesp, 2000), 90-105.

27 Nuno Marques Pereira, Compêndio narrativo do peregrino de América, em que se tratam vários discursos espirituais, e morais, com muitas advertencias, e documentos contra os abusos, que se achaõ introduzidos pela melicia [sic] diabolica no estado do Brasil (Lisbon: Fernandes da Costa, 1728).

28 John Bunyan, The Pilgrim's Progress from This World to That Which Is to Come: Delivered under the Similitude of a Dream (London: Ponder and Peacock, 1678); modern edition by Roger Sharrock and J.B. Wharey (Oxford: Oxford University Press, 1975). 
to Brazil," published in Paris in $1578 .{ }^{29}$ The second wave came with the arrival of Dutch Calvinists in northeastern Brazil between 1624 and 1654. In 1630, the Dutch settled in the regions of Recife and Olinda, then spread out to the rest of the Northeast; they had come to build a reformed church, and it obtained for over twenty-four years. Churches were built, sermons were preached, and missionary activity among the Indians was undertaken.

When Gusmão wrote his novel, the Calvinists were active in Brazil, and they had settled near areas of Jesuit missionary work. Thus the theological debate between the two positions and the competition for mission space inevitably pervaded the day-to-day religious life of the colony. In this debate, the goal of Gusmão's text was clearly indicated by the choice of the names of the two protagonists: Predestined and Reprobate. The difference between the two brothers, born of the same mother (who affirms that the universal human condition is to be a pilgrim), is also reflected in their choices of marital partners: "Predestined was married to a saint and honest virgin, called Reason, while Reprobate was married to a bad and corrupt female, called Own Will."30 These choices symbolize the difference in the personality of the characters: the first suggests the use of rationality; the second, the assertion of will. There are, in fact, two possibilities inherent to human beings and constantly involved in their choices: they can live according to reason or to will. In this sense, these choices give rise to different attitudes, metaphorized by the children of the two couples: "Predestined had two sons of his wife Reason, a male named Good Wish and a female named Straight Intent." Reprobate also had two sons with Own Will, "a male named Bad Desire and a female named Crooked Intent."31 Desire or sensory appetite (affection) and changes based on will (intent), can be guided by reason and so be good and proper; or they can be guided by will, thus being evil and twisted. This choice depends on early childhood education, as the author pointed out: "He [Predestined] knew how much damage could come from raising young children allowed to be controlled by their own will." ${ }^{32}$ Reason is characterized by "the view of insightful eyes"; on the contrary, Own Will is "all a product of appetite" and "blind in both eyes."33

The difference between the novel's two protagonists seems to indicate the result of the process of discernment undergone by Loyola in the face of

29 Jean de Léry, Histoire d'un voyage faict en la terre du Brésil (Paris: LGF, Bibliothèque Classique, 1994).

30 Gusmão, Historia, 8.

31 Ibid., 7 .

32 Ibid., 8 .

33 Ibid., 11. 
the movement of his spirit, as reported in his so-called Autobiography. Ignatius mentions having noticed a "difference" in himself: "the thought of worldly things initially raised a lot of pleasure; but then made him feel dissatisfied and unhappy. On the contrary, the thought of going to Jerusalem, made him happy and joyful." ${ }^{34}$ Similarly, Reprobate, entertained by a worldly horizon, experiences apparent satisfaction, but the outcome of his itinerary brings him to despair. Predestined, by contrast, suffers hardships along the way, but gradually experiences the joy of approaching the goal, joy which turns out to be jubilation in the end. The experience reflected on provided Ignatius with greater knowledge of himself ("insight"), as reported by the autobiographical narrative: "So he reaped from experience that some thoughts were sad and others cheerful. So little by little he came to know the diversity of spirits that moved him." ${ }^{35}$ Similarly, reading the novel should provide the reader with insights about him/herself and the path to follow in his/her life in the face of more than one destination: Jerusalem or Babylon. For the purpose of Gusmão's novel was precisely to highlight these differences in the two protagonists.

In addition to these differences arising from individual choices, Gusmão stresses that the human condition involves dealing with the same opportunities. The costumes and ornaments available to the two pilgrims for the journey are the same: both "out of habit put on the grace that they called baptismal," their shoulders have a lambskin cover that symbolizes the "Lamb of God, Charis," or "Divine Protection." "They put the hat, which they called Memory of Salvation, on their heads"; "They took in their hands the pilgrim's staff, which was called Fortress of God. It was cut off a tree which only grew in Paradise."36 On their feet they put "sandals, one of which was said to be Continuation, and the other, Perseverance; over their shoulders they tossed a saddlebag full of good intentions; around their waists they strapped a small gourd, which they called heart, full of a wine they called spiritual comfort." Finally, "in the bag they put three coins representing what they are generally used to buy, called Good Looks, Good Promises and Good Talk." The events following the departure highlight the impact of the exercise of human freedom on reality, i.e. on the circumstances of one's life (represented by the metaphor of the forest and other vegetation). This region, as the author points out, is "full of a thousand cliffs" and "hindrances," "difficult to pass." ${ }^{37}$ The judgment about the best course to follow depends on a decision in relation to a recognized goal, which

\footnotetext{
34 Loyola, Autobiography, n. 8.

35 Ibid., n. 23 .

36 Gusmão, Historia, 13 .

37 Ibid., 14.
} 
in turn depends on the wish-fulfillment that characterizes the human being: both pilgrims aspire to happiness. This is shown by the difference between loving oneself as a final destination (destiny) and loving oneself as the reflection of immediate circumstances. Both involve a laborious journey, but each person positions himself according to a distinct type of love.

Decisive in this regard is the role of education. In the novel, the quality of the children's schooling was crucial: the school to be chosen could be that of a woman called Truth or that of one called Lie. ${ }^{38}$ Depending on the choice, different learning opportunities were provided: "Behold the children of both arrive from school, referring to lessons learned that day." On the one hand, "the children of Predestined referred to the excellences which the Holy City of Jerusalem preached through the Prophets." On the other hand, "the children of Reprobate repeated the magnitudes of Babylon referred to by the scriptures." 39 In other words, the school provided targets for the intentions and desires of each, the ultimate goal being the very meaning of life, metaphorically portrayed by the two cities of Jerusalem and Babylon. From there, they would begin a journey of personal and collective history, the pilgrimage.

What was at stake in the journey was the destination of the individual person, another important theme conveyed by the novel. The protagonists of the novel, Predestined and Reprobate, embody the concept of a person within the cultural tradition of the Christian West. The Jesuits were the exponents of this concept in the context of Brazil's modern age, using the cultural tools available in their cultural background and developed in the College of Arts in Coimbra. Among these, we can highlight the Conimbricenses, a treatise drawn up by the teachers of the college and used for philosophical studies in the Society's schools in Brazil. ${ }^{40}$ In Brazil, various texts were produced by the Jesuits

38 Alexandre de Gusmão wrote several educational texts; among them Arte de criar bem os filhos na idade da puerícia (Lisbon: Officina de Miguel Deslandes, 1685). An awareness of the importance of educational work by the Society of Jesus permeates this entire treatise, from the "Prologue to the Reader," where Gusmão wrote: "It is so appropriate for the Society of Jesus to provide a good education for boys in the first years of childhood, that this was specifically mentioned in the presentation of its goals, because the founder, illuminated by the Holy Spirit, felt this should be a special obligation of the Society, with one of its principles being the teaching of good arts and the implantation of good habits in all for the greater glory of God and the well being of their souls" (Gusmão Arte de criar bem, I).

39 Gusmão, Historia, 13.

40 The treatise contains comments on the Greek texts of Aristotle. In the case of anthropological and psychological studies, the following texts are especially relevant: Manoel de Góis, Commentarii Collegii Conimbricensis Societati Iesu, in tres libros de anima 
in order to advance the anthropological vision which underlay their knowledge and practices: the Diálogo do Padre Nóbrega sobre a conversão do gentio, in which the Jesuit Manuel da Nóbrega (1517-70) applied the AristotelianThomistic concepts of person, human soul, and psychological powers (namely understanding, memory, and will) to justify the humanity and the convertibility of the Indian. ${ }^{41}$ The theme of the person was also central in Gusmão's other works. In Arte de criar bem os filhos na idade da puerícia, he compares the characters of boys to the various metals found in mines, which have different values and properties. However, just as there is no metal (even one of low alloy) that does not have some utility and value when worked by art, "there is no boy, however bad his condition may be, that cannot be tamed by good education."42 In Eleição entre o bem e o mal eterno, Gusmão recommends caring for the soul. Such a position is not necessarily obvious: soul is an invisible reality and taking

(Coimbra: Mariz, 1589); Góis, Commentarii Collegii Conimbricensis Societatis Iesu, in libros Aristotelis qui Parva Naturalia appellantur (Lisbon: Simão Lopes, 1593); Góis, In libros Ethicorum Aristotelis ad Nicomachum aliquot Conimbricensis cursus disputationes, in quibus praecipua quaedam Ethicae disciplinae capita continentur (Lisbon: S. Lopes, 1593); Góis, Commentarii Collegii Conimbricensis Societatis Iesu, in libros de generatione et corruptione Aristotelis Stagiritae nunc recens omni diligentia recogniti et emendati (Coimbra: Mariz, 1597). See Marina Massimi, "A psicologia dos jesuítas: Uma contribuição à história das idéias psicológicas," Psicologia: Reflexão e crítica 14 (2002): 625-33.

41 The text is found in Manoel da Nóbrega, Cartas do Brasil (Belo Horizonte: Editora Universidade de São Paulo-Editora Itatiaia, 1989), 229-45. It is a discussion in dialogue form-a rhetorical model that was widely used in the sixteenth century-between two positions, both widespread among the Jesuits on a mission in Brazil, one stating the possibility of conversion of Indians, based on the fact that they had all the elements of human nature, especially in relation to a mental life, and the other questioning this possibility, given the great difficulties faced by the missionaries and the impediments presented by the Amerindians themselves in relation to evangelization. Two characters-Matheus Nogueira and Gonçalo Alves - represent these two views. In one of the high points of the conversation, Nogueira mentions as a basis for his belief of the possibilities of missionaries of the Society with the Amerindians, the fact that they are clearly full-fledged human beings, and said, "I am imagining all the souls of men to be [the same]" (Nóbrega, Cartas, 237). The statement that the Amerindians have souls equal to those of European men is shown by the fact that "the soul has three powers, understanding, memory and will, which all have." Once the Indian is recognized as a person, the question of efforts to assist in his development of an adequate awareness of himself and suitable behavior arises. This brings up the importance of education: The fact that the Romans and other Gentiles were better educated does not mean that they had a naturally better understanding, but rather that they had been raised better and were brought up with more civil understanding" (Nóbrega, Cartas, 240). 
care of it requires going beyond appearances. The sense of sight reveals the beauty of the body, while the beauty of the soul is revealed to us only by the inner senses. This knowledge is critical: "Love depends on the knowledge we have of our souls, and on that love depends our salvation."43 In this context, the Story of the Pilgrim Predestined and His Brother Reprobate was designed to highlight the importance of and the ways of achieving this, as if to correct for the effects of carelessness: a person fulfills himself/herself only insofar as he/ she develops towards his/her final destination. Thus, a person's knowledge and the exercise of that person's power to act coincide in the novel.

The three dynamics that make up the unitary person (spirit, soul, body) are clearly visible in the novel. The body is inseparable from the psychological and spiritual dimensions: we have seen that the physical act of a pilgrimage involves both the psychological and the spiritual. Indeed, according to the Aristotelian-Thomist conception conveyed by the Conimbricenses treatise, the power of movement in man is directed by reason, unlike what happens in animals, where it is governed only by instinct. ${ }^{44}$

As for spiritual dynamism, we have seen that human existence as a pilgrimage is the thematic core of the novel, as clearly indicated in the concluding portion, where the author provides the key for interpreting his metaphors:

Now I ask thee, who reads this, which is presented to you as a parable, is not this what really passes between us? Isn't it true that we are all brothers, children of the same father, who is God? Isn't it true that all of us in this life, as long as we live, are like pilgrims, or like the homeless, and that our homeland is heaven, and the earth exile? ${ }^{45}$

First, Gusmão urges the reader to be devout: "Behold, devout reader, the end of all the paths of our pilgrim Predestined," 46 i.e., this reading implies not only the involvement of cognitive powers, but also spiritual attitudes, such as devotion. Second, the author highlights the importance of the destination chosen

43 Gusmão, Eleição, 341.

44 Also according to the Conimbricenses, one must know the "natural composition" of the body of each person. This knowledge is discussed in Manuel Góis, Commentarii Collegii Conimbricensis Societatis Iesu, in libros de generatione et corruptione Aristotelis Stagiritae nunc recens omni diligentia recogniti et emendati (Venice: Tipografia Vincenzo Amadino, 1607), 661-64. See Marina Massimi, "A pessoa e o seu conhecimento: Algumas etapas significativas de um percurso," Memorandum 18 (2010): 10-26; Massimi, A teoria dos temperamentos e suas aplicações nos trópicos (Ribeirão Preto: Editora Holos, 2010).

46 Ibid. 
by the protagonists. Third, he marks the dynamic dimension of the human condition as a whole, "we are all pilgrims in this life." Fourth, as we have seen, the novel points out that the destination and, therefore, the meaning of each existence is predetermined, but depends on insights and the free choice of the person to choose the direction they take. The story of Reprobate shows that the capacity for discernment depends not only on "good intentions" and good company, but also on precautions against being deceived by one's own will. Such illusions can cause a person to abandon either the good intentions or the good company, thus becoming entangled in vanity, idolatry, pride, and a false concept of freedom. We have seen that such an illusion immediately appears as "delights," but soon after is revealed in the true aspect of "confusion" (represented by Babylon, the infernal city). ${ }^{47}$ The disillusion that leads to the correct understanding of reality requires trust in the "advice of reason," which commends the traveler to follow "in the footsteps of Christ," learning to live in a way consistent with the same virtues as that divine person: devotion, piety, obedience, penitence/repentance, perseverance in the face of trial, and so on. In this way, it will be possible to reach "Jerusalem, the fortunate termination of his pilgrimage, where he will live eternally with his king, who is Christ," and where the pilgrim will be transformed into "one of the blessed citizens." 48 In summary, one of the important anthropological concepts of the Jesuits is clear in the novel: for a human being to be complete, reason must control personal instincts: existence in agreement with reason and desire subject to an otherness, and not mere affirmation of itself.

The interactions between spiritual and psychological dynamism are decisive in relation to the power of the soul, and its operation, diseases, and remedies. ${ }^{49}$ Psychological powers arise at the interface between the body and the spirit. The occurrence of some disorder in these powers permits the installation of "evil inclinations" within people. In the journey of the two pilgrims, psychological powers are figured through the image of a hydraulic system composed of springs, canals, and streams. According to the narrative, "these springs are nothing more than the two main powers of our soul, understanding and desire,

47 Ibid., 360 .

48 Ibid., 361.

49 The link between appetites and spiritual values is discussed in the Ethics. One of the authors of Conimbricenses, Góis, stated that the act of hungering for something is proof of the desire of all for that object, in the face of previous sensory knowledge. In the case of humans, this object can be identified as inappropriate in relation to proper reason and the divine law. When greater good opposes a natural phenomenon, man must be able to discern between them and choose the right one. Góis, Commentarii Collegii Conimbricensis Societatis Iesu, in libros Aristotelis qui Etica Nicomaci appellantur, 83. 
from which good and bad originate. ${ }^{50}$ Their operation occurs through the mediation of other psychological powers. ${ }^{51}$ Springs "run through two pipes that are called Sensory Appetites, one whose name is Irascible and the other Craving." In turn, these feed into eleven streams called Passions, "the seven of craving are called Love, Hatred, Desire, Abomination, Delight, Pleasure, and Sadness; the pipes of Irascible are called Hope, Desperation, Boldness, Fear, Anger, and Indignation." The springs can be clean or dirty, and this regulates the functioning of the canals and streams. In this description of the psychological aspect Gusmão appears to adhere to the Aristotelian-Thomistic position of the Conimbricenses, presenting the dynamism of Reprobate: the cause of his deviations are not the exercise of desire itself, but the fact that it is misdirected, because it is not subjected to reason. From the union with his wife Own Will, Reprobate fathers other children: "Contempt of Eternal Things and Esteem of Temporal Things." Arising from the paths Reprobate chooses is an internal imbalance of powers: his daughters "Hardheartedness, Blindness to Understanding, Stubbornness of Volition" transform him "in such a way that he did not seem to be a man of reason." 52 He was affected at the end of the story by a "confusion" that plagued him "with a thousand sorrows, griefs and anxieties" and a "snake of terrible aspect," a metaphor for his "own conscience," surrounded him with "twists and turns which are called imagination" and bit his heart with "three teeth." The first was the tooth of volition, which "crossed his heart with stubborn or eternal despair;" the second is memory, which "bit his heart with the memory of the brief delights for which he had earned those torments;" and the third, the understanding that "crossed his heart with the representation of his

$50 \quad$ Gusmão, Historia, 260.

51 A similar design of the psyche of the Aristotelian-Thomistic matrix can be found in comments in the Conimbricenses on De anima, Parvas naturalia and the Ética a Nicômaco. The psychological powers of the soul are classified into five types: a vegetative power with nutritive and generating functions; a sensory power, responsible for sensory knowledge which acts via the external senses (sight, hearing, smell, taste, touch) and the inner ones (functioning to integrate the sensations from the five outer senses, distinguishing them and comparing them with each other); fantasy or imagination, which makes up and separates the sensations from each other; the cogitative or evaluative power; and memory. The power of appetite is composed of the sensory appetite, oriented towards unique and sensory objects (i.e, passions, or an affective life as such) and the power of the intellectual appetite, driven by reason. Intellectual power is composed of intuitive intellectual knowledge (information about a physically present object) and abstract intellectual knowledge (apprehension of an object that is not present).

$5^{2}$ Gusmão, Historia, 247. 
brother Predestined, who was glad to be arriving at the gates of Jerusalem." ${ }^{53}$ In short, Reprobate is a typical example of deviation from a target due to willfulness, a deviation that brings about the disorder of human acts. To a certain extent, Reprobate's will has regressed to the level of the passions and sensory appetites. Therefore, for a good life, the control of appetites and other powers, and the identification of the "diseases" of the soul, the development of which is described in great detail by Gusmão, become critical. He portrays psychological illness in analogy to a disease of the body as an "infection" resulting from the infiltration of the waters of the springs (powers) by evil intentions. So, "the first spring, Understanding, is infected with a sticky slime of Bad Principles; the second spring, Will, is infected with another called Bad Influences." ${ }^{44}$ This infection leads to the fact that "if [the] will is depraved by the disordered sympathies of our passions," it becomes impossible to "reach an understanding of the truth" and "a desire for good." This view is consistent with the philosophy of the Aristotelian-Thomistic psychology found in Conimbricenses: affections or passions are inclinations of the sensory appetites that motivate desire. These inclinations should be mediated by reason. ${ }^{55}$ If they are not, the sensory appetite may be driven by desire under the pressure of the internal senses, including imagination, so that it becomes dominated by the appetites, and reason loses control of personal dynamism. ${ }^{56}$

The disorder of the human experience, portrayed in the story of Reprobate, is the "disease" that the Jesuit training, proposed by Loyola and his followers, sought to "cure" through the systematic task of ordering personal dimensions. In Gusmão's novel, the remedies proposed for Predestined correspond to the great pillars of Jesuit pedagogy: proper use of reason in search for truth, goodness, and morality (proper intentions and good desire). These, in turn, will be able to control desire and passion. Predestined is advised to give himself up

\footnotetext{
53 Ibid., 315 .

54 Ibid., 261.

55 According to Conimbricenses, appetite drives will "through the intellectual news" of the object (thus guiding the decision "whether the object should be accepted or rejected"). Góis, Commentarii Collegii Conimbricensis Societatis Iesu, in libros Aristotelis qui Etica Nicomaci appellantur, 159 .

56 When passion appears this way in the soul's life, it becomes an inclination of intense and disordered appetite that "disrupts and absorbs judgment," to the point that "it takes away the power to decide" (ibid., 161). It is, however, a very specific condition. In general, "ease of movement is free to the extent that the judgment integrates and remains free." This position is reiterated by the commentator also in the fourth dispute of the same treatise, in which the dynamism of the will is discussed: this is free when "it follows the previous resolution of the intellect." Ibid., 139 .
} 
to the cares of his "Wife Reason and his two sons, Good Desire and Straight Intention."57 "Straight Intention" will clarify understanding and "Good Desire" will take care of the control of desire. In the Jesuit tradition, and in the Catholic one in general, this task is called "enlightenment." ${ }^{58}$ In the novel, Enlightenment is a character who advises Predestined, and who is portrayed as someone who "focuses on the Truth." At this time, the pilgrim receives a torch from an angel, a torch made of very pure wax, "produced by bees that are called Powers of the soul," from the pollen of "flowers relocated from Paradise to the garden of the Catholic Church by its own Gardener, which is the Holy Spirit." Thus, Gusmão highlights the fact that enlightenment is in part brought about by the operation of psychological dynamism: bees (the powers of the soul) play an active role in the process. On the other hand, for the wax to be "very pure," "flowers" from Paradise are necessary, i.e. divine grace. Here, Gusmão affirms the Jesuits' theological position on the relationship between human freedom and divine initiative, a relationship questioned by the Protestant doctrine emphasizing the predominance of grace..$^{59}$

A belief in the crucial role of the powers of the soul in the process of enlightenment requires knowledge about its operation, and this justifies the attention paid to the psychological dimension in Jesuit anthropology.

\section{Conclusion}

The plot of the novel is the topos of the pilgrimage as a figure of life, shaped by the Judeo-Christian tradition. As part of their theological and philosophical view of the world, the Jesuits conceived of the human condition as marked by a teleological temporality aimed at final destination. Freedom, a constitutive dimension of personal dynamism, turns man into an active protagonist in the linear course of time: history. A pilgrimage must be understood not only from the perspective of the conceptual universe, but also as an ortho-praxis: the realization of a path of reflection which, using various rhetorical devices, is designed to model a person's experience to make it more orderly, so that the ideal destination will be attained; one's freedom must be used appropriately to achieve that end. Gusmão's novel thus provides a virtual roadmap to

57 Gusmão, Historia, 261.

$5^{8}$ Disappointment as true understanding of reality is also covered in sacred oratory, which is the instrument par excellence of this knowledge. See Marina Massimi, Palavras, almas e corpos no Brasil colonial (São Paulo: Edições Loyola, 2005).

Franco Buzzi, Teologia e cultura cristiana tra XV e XVI secolo (Genoa: Marietti, 200o). 
be followed by the reader as he or she accompanies the two protagonists. The goal is to impress upon the person that reaching one's destiny is made possible by the proper use of what is provided. Among these provisions is the fact that the life of the soul has a fundamental role in the relationship between the body and the spirit. 